coloured under-wings. Of these fifteen all have some more or less transparent spaces or colourings. In some cases portions of the under-wing; are brightly coloured, though not transparent, but both in this case and when there are transparent places they appear chiefly on parts that are apparently invisible when the wings are closed. If these observations are correct, the insects are carefully protected when at rest or when they are laying their eggs. Whether they pair on the ground or with shut wings I do not actually know, for after carefully watching every butterfly I have come across for two summers, I have not succeeded in seeing any of the protectively coloured sorts pairing. It seems likely enough therefore that their protective colours come into flay then. My opportunities for observation are however extremely limited, and it is to draw the attention of those more favourably situated to the subject of the colours of our common butterflies that I write this. In the fifteen protectively-coloured butterfices mentioned above I did not include the "fritillaries," because of the strange metallic lustre on their under-wings. Still they seem suddenly to disappear when they settle, and the metallic spots may take the place of the transparent or coloured ones in other sorts by throwing off the light, and thus enable the insects to recognise each other. Eight linds more or less transparent but not seemingly protectively coloured, and two common "Blues," make up the thirty kinds I have been able to handle. The under-wings of the "Blues" are certainly protectively coloured, but there seems to be no transparency or bright markings in them.

Putney, February 24

\section{Dust, Fogs, and Smoke}

THE present endeavours to alleviate the smoke nuisance in London give some interest to the description of the effects of coal smoke on London life in former ages.

I do not mean to speak of the well-known petition presented to Edward the First by the nobility and gentry against the use of sea-coal in London and the consequent proclamation of that monarch interdicting its use. But I allude to the following lines written and published by Evelyn in $166 \mathrm{r}$ in his "Fumifugium," but which I borraw from the "History of London," by Noorthouck, London, I773.

"The immoderate use of, and indulgence to sea-coale alone in the city of London, exposes it to one of the fowle it incon veniences and reproaches, that can possibly befall so noble, and otherwise incomparable city: and that, not from the culinary fires, which for being weak and lesse often fed below, is with such ease dispelled and scattered above, as it is hardly at all discernible, but from some few particular tunnells and issues, belonging only to brewers, diers, lime-burners, salt, and sopeboylers, and some other private trades one of whose spiracles alone, does manifestly infect the aer, more than all the chimnies of London put together besides. And that this is not the least hyperbolie, let the best of judges decide it, which I take to be our senses: whilst these are belching it forth their sonty jaws, the city of London resembles the face rather of Mount $A$ tna, the court of Vulcan, Stromboli, or the suburbs of hell, than an assembly of rational creatures, and the imperial seat of our incomparable monarch. For when in all other places the aer is most serene and pure, it is here ecclipsed with such a cloud of sulphure, as the sun itself, which gives day to all the world besides, is hardly able to penetrate and impart it here; and the weary traveiler, at many miles distance, sooner smells, than sees the city to which he repairs. This is that pernicious smoalie which sullyes all her glory, superinducing a sooty crust, or fur upon all that it lights, spoyling the moveables, tarnishing the plate, gildings, and furniture, and corrodding the very iron bars and hardest stones with those piercing and acrimonious spirits which accompany its sulphure; and executing more in one year than exposed to the pure aer of the country it could effect in some hundreds. It is this horrid smoake which obscures our churches and makes our palaces look old, which fouls our clothes, and corrupts the waters, so as the very rain and refresh. ing dews which fall in the several seasons precipitate this impure vapour, which with its black and tenacious quality, spots and contaminates whatever is exposed to it. It is this which scatters and strews about those black and smutty atomes upon all things where it comes, insinuating it elf into cur very secret cabinets, and most precious repositories: finally, it is this which diffuses and spreads a yellownesse upon our choysest pictures and hangings; which does this mischief at home, is Avernus to fowl, and kills our bees and flowers abroad, suffering nothing in our gardens to bud, display themselves or ripen; so as our anemonies and many other choycest flowers will by no industry be made to blow [sic] in London, or the precincts of it, unlesse they be raised on a hot-bed and governed with extraordinary artifice to accellerate their springing; imparting a bitter and ungrateful tast to those few wretched fruits, which never arriving to their desired maturity seem, like the apples of Sodome, to fall even to dust when they are but touched. Not therefore to be forgotten is that which was by many observed, that in the year 1644 when Newcastle was besieged and blocked up in our late wars, so as throngh the great dearth and scarcity of coales, those fumous works many of them were either left off, or spent but few coales in comparison to what they now use; divers gardens and orchards, planted even in the very heart of London (as in particular my lord Marquesse of Hertford's in the Strand, my lord Bridgewater's and some others about Barbican), were observed to bear such plentiful and infinite quantities of fruits, as they never produced the like either before or since to their great astonishment : but. it was by the owners rightly imputed to the penury of coales and the little smoake, which they took notice to infest them that year; for there is a virtue in the aer to penetrate, alter, nourish, yea and to multiply plants and fruits, without which no vegetable could possibly thrive."

The improvement mentioned by Evelyn, when the use of coal was for a time less extensive in London, is particularly worthy of notice, and ought, I think, to be considered as an encouragement to persist in the attempt of rendering London as smokeless as possible.

Jersey, February 25

\section{THE GERMAN CHEMICAL SOCIETY}

$\mathrm{N}^{\mathrm{N}}$ November II, 1867, a meeting of about eighty chemists was held in Berlin to take steps for inaugurating a new Chemical Society. On January I 3 of the succeeding year (1868) the first meeting of the Society was held, when Prof. A. W. Hofmann was elected president, and the roll call of the Society contained 105 names. During the first year of its existence 97 papers were read before the Society; at the close of the year the membership had increased to 275 , and the Society found that a volume of 282 pages was needed to contain the papers communicated to it.

Since 1868 the German Chemical Society has steadily increased in size and in usefulness; the Berichte for 1880 consists of two large volumes numbering, between them, 2473 pages, and containing the 563 papers communicated to the Society during the year, besides numerous abstracts of papers published elsewhere. The income of the Society for I 880 amounted in round numbers to the sum of $2000 \mathrm{l}$., and of this about $1400 \mathrm{l}$. was set against the cost of publishing the Berichte.

During the thirteen years of its existence the German Chemical Society has published in its Berichte most of the important discoveries in pure chemistry made in that period. It has been the aim of the Society to publish papers communicated to it with as little delay as possible. Meetings are held twice monthly during the session, and the papers read at one meeting are published in the Berichte, which appears on the day on which the next meeting takes place. Papers appearing within so short a time after they are communicated are necessarily brief and concise; but this rapid publication confers a great benefit on all chemists, as they are thus put in possession of at least the leading facts concerning all recent work almost as soon as these facts have been established by the workers. If papers in the Berichte are sometimes wanting in completeness and symmetry, many of them are full of life and stir, telling as they do of work actually proceeding in the laboratory; appearing sometimes in short abrupt snatches, they convey something of the enthusiasm of the worker as he compels nature, bit by bit, to yield her treasured secrets.

The system of printing abstracts of papers published in the various chemical journals has recently been adopted 
by the Society; formerly a correspondent in London or Paris, \&c., sent a general account of chemical work published in the country from which he wrote. The abstracts of the German Society are on the whole shorter than those which have for many years made the Journal of our own Chemical Society of such great value to the student; they are, however, published at a shorter interval after the appearance of the original paper.

Brief accounts are given of recent chemical patents, but little space is devoted to purely technical chemistry. Is not the fournal of the Chemical Society sometimes overburdened by abstracts which might better find a place in a book professing to collect receipts for the purely "practical man"?

The German Chemical Society in 1877 appointed Dr. C. Bischof of Berlin to prepare a general index for the first ten volumes of the Berichte. The arduous task has been admirably fulfilled. Fellows of the Society have now in their hands not only an index to the Berichte, but a volume which is really a general guide to the chemical work published during the period 1868-I 877 .

The "Generalregister" extends to Iozo pp.; of these, $162 \mathrm{pp}$. are devoted to an index of authors, $732 \mathrm{pp}$. to an index of subjects, $42 \mathrm{pp}$. to an index of patents, and 84 $\mathrm{pp}$. to a systematic classification of the carbon compounds referred to in the index.

Under an author's name are given, not the exact title of his paper, but a very succinct statement of the leading points in the paper. The same method is pursued in the subjects-index. Taking, for instance, such a general subject as "Dissociation," one finds, first, references to work on the general Theory of Dissociation, e.g. connection between dissociation and temperature, tension, \&c. ; then follow special instances of dissociation, inorganic compounds preceding organic. In the case of individual elements or compounds, the references begin with those papers on the existence of the substance in question, then follow its preparation and formation, its properties, its action on other substances, the action of other bodies on it, its estimation, \&c., \&c.

A systematic nomenclature is adopted, more especially for the carbon compounds: the principles which guided the compiler are stated in a few introductory pages.

The "Generalregister" cannot but be of the greatest value to chemists generally. Almost every chemist is a Fellow of the German Society; many possess the Berichte complete up to date; with the Berichte and this admirable guide which Dr. Bischof has supplied, they can find almost everything that has been done in experimental chemistry within the period $1868-1877$. M. M. P. M.

\section{IRISH ESPARTO GRASS}

$\mathrm{T} \mathrm{T}$ is now over two years ago since attention was called in our pages to the importance of the purple Molinia (Molinia carulea) as a material for making paper. Mr. Christie of Edinburgh sent a small quantity of it to be operated on by Mr. T. Routledge of Sunderland, and the report on this was most favourable. In January, 1879, a notice appeared in the Times also calling attention to the subject, and referring to the above favourable report; it expressed the hope that some effort would be used to have this grass collected on an extensive scale. It would seem to be ripe for gathering in the early autumn, when some hands could be spared for such work, and as the ground on which it flourishes - wet or partially drained bogs-pays, at least in Ireland, little if any rent, the crop would cost little over the expense of reaping it. Since the first notice appeared in our columns, the Spanish and African Esparto grass has been getting more difficult to obtain, and the demand for it has been steadily on the increase. It is said that the greater part of what is gathered in Morocco finds its way to the Times papermills, and its value for paper-making is now known in
America. Several analyses of specimens of the dried hay made from this grass are given in a paper by Dr. Cameron, "On the Composition of a Crop of Hay" (Proc. Roy. Dub. Soc., n.s., vol. ii. p. IOI); we select one of these, which yielded as follows :-

\section{0 parts contained-}

$\begin{array}{lccccr}\text { Water } \ldots & \ldots & \ldots & \ldots & \ldots & 27 \cdot 95 \\ \text { Albuminoids } & \ldots & \ldots & \ldots & \ldots & 7 \cdot 49 \\ \text { Fats } \ldots & \ldots & \ldots & \ldots & \ldots & 2 \cdot 70 \\ \text { Non-nitrogenous } & \text { substances } & \ldots & \ldots & 30^{\circ} \circ 0 \\ \text { Woody fibre } & \ldots & \ldots & \ldots & \ldots & 31 \cdot 26 \\ \text { Mineral water } & \ldots & \ldots & \ldots & \ldots & 0.60 \\ & & & & & \text { 100.00 }\end{array}$

\begin{tabular}{|c|c|c|c|c|c|c|}
\hline \multicolumn{7}{|c|}{ And of this the ash contained- } \\
\hline Lime & $\ldots$ & $\ldots$ & $\ldots$ & $\ldots$ & $\ldots$ & $28 \cdot 86$ \\
\hline Magnesia & $\ldots$ & ... & $\ldots$ & $\ldots$ & $\ldots$ & $4 \cdot 76$ \\
\hline Potash an & d soda & $\ldots$ & $\ldots$ & $\ldots$ & $\ldots$ & $42 \cdot 17$ \\
\hline Phosphor & ic acid & $\ldots$ & $\ldots$ & $\ldots$ & $\ldots$ & 12.36 \\
\hline Sulphuric & acid & & $\cdots$ & $\ldots$ & $\ldots$ & 5.9 \\
\hline Oxide of & iron an & d al & ina & $\ldots$ & $\ldots$ & 1.0 \\
\hline Chlorine & $\ldots$ & $\ldots$ & $\ldots$ & $\ldots$ & $\ldots$ & $4 \cdot 32$ \\
\hline Silica & $\ldots$ & $\ldots$ & $\ldots$ & $\ldots$ & $\ldots$ & 0.5 \\
\hline
\end{tabular}

This freedom from silica of the purple Melic grass is very remarkable.

From a paper by Mr. W. Smith in the recent number of the Proceedings of the Royal Dublin Society, we learn that a very successful trial has been made in the county of Galway to grow this grass in some quantity. As a native plant it is found in every county in Ireland, both on wet heaths and boggy pastures. It flowers in July and August, and its seeds are ripe early in September; it would seem to grow well on partially drained bogs, and if the surface of these has been burnt, the purple Melic grass grows thereon most luxuriantly. It seems fond of growing in tufts, of somewhat large size, and it does not form a sod like so many other grasses. It would appear that in Ireland alone there are over $1,000,000$ acres at the present moment not worth sixpence a year each for any agricultural purpose ; each acre would easily grow half a ton weight of dried Melic grass, which at its lowest value would be worth $2 l$. Would not this crop, in time, more than compensate for the loss of the potatoe? It seems a pity that the manufacturer should have to go to the Port of Mogador for what he might get with so much greater ease at the Port of Dublin.

\section{SIBERIAN METEOROLOGY}

U $\mathrm{P}$ to the present time Yakutsk, in North-east Siberia, has often been cited as the place of our earth where the winter is coldest, while the minima observed during Arctic expeditions are believed to be the lowest known. Neither the one nor the other is true. In Maak's book, "Olekminski Okrug," I find many data which prove that the coldest winter as well as the lowest well-authenticated minima were observed at Werkhojansk, to the north-east of Yakutsk. The name of the author gives us some guarantee that the observations are trustworthy. I give below the minima at some places cited by Maak, and compare them with those observed in Central and Western Siberia, and the Arctic Archipelago of America:-

\section{North-East Siberia}

Serdze-Kamen. $67^{\circ}$ N. $173^{\circ}$ E. (Nordenskjöld) $-50^{\circ} 3 \mathrm{~F}$.

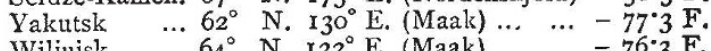

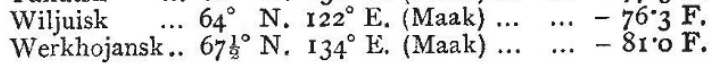

$$
\text { Central and West Siberia }
$$

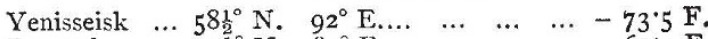

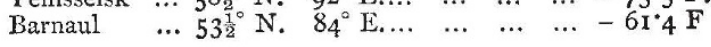

